\title{
Explaining variation in organizational change: the reform of human resource management in the European Commission and the OECD
}

\author{
Christoph Knill and Tim Balint
}

\begin{abstract}
In this article we investigate the reforms of human resource management in the European Commission and the OECD by analysing comparatively to what extent both organizations have adjusted their respective structures towards the ideal type of the so-called new public management (NPM). The empirical findings show that reforms towards NPM are more pronounced in the Commission than in the OECD. These findings are surprising for two reasons: first, it seems paradoxical that the OECD as central promoter of NPM at the international level lags behind the global trend when it comes to reforming its own structures. Second, this result is in contradiction to theoretical expectations, as they can be derived from theories of institutional isomorphism. Nevertheless, to account for the surprising results, it is necessary to modify and complement existing theories especially with regard to the scope conditions of their causal mechanisms.
\end{abstract}

KEY WORDS European Commission; human resource management; institutional isomorphism; new public management; $\mathrm{OECD}$; organizational change.

\section{INTRODUCTION}

Much scholarly attention has been devoted to investigation of the driving forces and consequences of the far-reaching national administrative reforms and changes in the public sector in the context of the global wave of new public management (NPM) that swept over Western countries from the early 1980s onwards (Hood 1991; Naschold and Bogumil 2000; Pollitt and Bouckaert 2004). Notwithstanding the fact that the pace and patterns as well as the fine-tuning of NPM reforms vary across countries, there is hardly any doubt that there is a converging trend away from classical Weberian bureaucracies towards more market-oriented management principles and structures. This process of international diffusion was to a considerable extent fuelled by the communication activities of international organizations, such as the Organization for Economic Co-operation and Development (OECD) in the early 1990s (Hood 1995; Lægreid 2002). 
In view of these developments, it is striking that management reforms within these international organizations themselves have so far hardly been subject to comprehensive investigations. We still have limited knowledge about the extent to which international organizations, often considered as crucial diffusion agents with regard to public sector management reforms, actually live up to the standards they promote. It is only recently that the role and functioning of international bureaucracies became a subject of growing importance (cf. Barnett and Finnemore 1999, 2004; Bauer and Knill 2007; Geri 2001; Hooghe 2001; Liese and Weinlich 2006).

In this article, we address this research gap by a comparative analysis of human resource management reforms in the European Commission and the Secretariat of the OECD. We analyse the extent to which both organizations reformed their human resource management structures and procedures in line with NPM principles. This selection of cases is based on the fact that the two organizations differ very sharply with regard to their reform record. While the Commission brought its management structures with regard to many dimensions closely in line with an NPM-like approach, the OECD, by contrast, still represents a more Weberian bureaucracy type when it comes to issues of human resource management.

Moreover, these findings are striking in light of the fact that the two organizations - notwithstanding their differences in terms of competences and nature (supranational versus international organization) - share many characteristics. Both organizations can be characterized as international bureaucracies where officials with similar educational backgrounds are employed. They were founded at around the same time and are based on legalistic structures and routines, reflecting the Continental administrative tradition.

In our following analysis we first specify our dependent variable reform of buman resource management (section 2). In a second step, we present our empirical findings and show why existing theoretical approaches derived from organization theory are not sufficient to account for our empirical puzzle (section 3). Based on these considerations we consider in a third step alternative explanatory approaches and theoretical modifications of existing theories (section 4). Section 5 concludes.

\section{EMPIRICAL FINDINGS: HUMAN RESOURCE MANAGEMENT IN THE EUROPEAN COMMISSION AND THE OECD}

To assess the reform of human resource management in the European Commission and the OECD we consider formal changes with regard to the categories recruitment, career structure, staff appraisal, and training (Davies 2002; Vaanholt 1997). The OECD and the European Commission regulate their human resource management by staff regulations and staff rules. The staff rules specify the execution of the regulations and can only be changed by the Secretary General. Changes to the staff regulations are subject to the approval of the member states represented in the Council. 
With regard to human resource management, we distinguish the ideal types of Weber's bureaucracy model (BM) (Vaanholt 1997) and the overall concept of NPM for human resource management (Liebel and Oechsler 1992; OECD 1995, 2005b; Pollitt and Bouckaert 2004). NPM is not a single and coherent reform concept and is differently defined, interpreted and implemented. Nevertheless, certain universal and internationally approved principles of NPM can be identified, hence representing a general model for reforms in human resource management (Naschold and Bogumil 2000: 84; OECD 2005b: 181). The ideal types and respective indicators are summarized in Table 1.

We first consider the range of reform by comparing existing patterns of human resource management to an ideal type NPM approach for 1995 and 2007. This gives us an idea about the extent to which each organization moved towards NPM-oriented structures during the observation period. In a second step, we examine the scale of reform by comparing the distance to the NPM ideal type for both organizations in 1995 and 2007. In this way, we can judge which organization reformed its human resource management more, and also which organization is now closer to the ideal type.

The extent to which the different dimensions of human resource management reflect either the BM or NPM ideal type is illustrated by an ordinal scale based on five categories, from 0 to 4 . The value 0 means that a certain indicator is fully in line with the BM model, value 4 implies full conformity with the NPM ideal. The other values indicate constellations in between the ideal types. Category 1 means that reforms are more BM than NPM, category 2 refers to cases in which characteristics of both ideal types are similarly represented, and category 3 implies that indicators are closer to NPM than BM, although not fully in line with the latter. This distinction is needed because of the fact that empirically we often observe mixtures between BM and NPM elements with regard to the different indicators.

\section{The reform of human resource management in the European Commission}

In the European Commission, staff regulations and rules apply to 23,000 permanent officials, most of them with contracts for life. Aside from this, there are specific regulations for around 7,000 temporary agents, contract agents, seconded national experts, auxiliaries, and trainees, who, however, are excluded from our analysis.

As far as recruitment is concerned, the merit principle is the most important criterion in the selection procedure (European Commission 2007b). But in addition to this, a paragraph in the staff regulations ensures national balance, i.e. an appropriate representation of member states' nationals. For senior managers, there is a very clear analysis of nationality in order to avoid overrepresentation or under-representation of certain nationalities, albeit without using a fixed quota (interview 12/05/2006). Furthermore, the standardized selection procedure is sometimes circumvented by 'parachutage', meaning that 
Table 1 Operationalization of the dependent variable

\begin{tabular}{|c|c|c|}
\hline Indicators & Value (BM) & Value (NPM) \\
\hline \multicolumn{3}{|l|}{ Recruitment } \\
\hline $\begin{array}{l}\text { selection procedure } \\
\text { in general }\end{array}$ & $\begin{array}{l}\text { formal conditions (e.g. } \\
\text { educational background), } \\
\text { national balance }\end{array}$ & $\begin{array}{l}\text { merit principle, sophisticated } \\
\text { selection methods }\end{array}$ \\
\hline $\begin{array}{l}\text { selection procedure } \\
\text { for senior staff }\end{array}$ & $\begin{array}{l}\text { imprecise selection } \\
\text { procedure, unrestricted } \\
\text { length of appointment }\end{array}$ & $\begin{array}{l}\text { formal selection procedure, } \\
\text { length of appointment } \\
\text { related to performance }\end{array}$ \\
\hline $\begin{array}{l}\text { profile of senior } \\
\text { staff }\end{array}$ & $\begin{array}{l}\text { expertise, limited } \\
\text { responsibility for resources }\end{array}$ & $\begin{array}{l}\text { management capabilities, } \\
\text { responsibility for resources }\end{array}$ \\
\hline \multicolumn{3}{|l|}{ Career structure } \\
\hline entrance & $\begin{array}{l}\text { usually first grade (salary } \\
\text { class) of the respective } \\
\text { career }\end{array}$ & $\begin{array}{l}\text { every grade is open to } \\
\text { competition }\end{array}$ \\
\hline structure & $\begin{array}{l}\text { horizontal and quite } \\
\text { impermeable }\end{array}$ & vertical and permeable \\
\hline basic salary & dependent on grade & $\begin{array}{l}\text { dependent on task and } \\
\text { responsibility }\end{array}$ \\
\hline extra pay & $\begin{array}{l}\text { paid automatically and } \\
\text { related to seniority }\end{array}$ & $\begin{array}{l}\text { performance-related pay for } \\
\text { every official }\end{array}$ \\
\hline merit bonus & none & $\begin{array}{l}\text { cafeteria system (e.g. } \\
\text { monetary and non-monetary } \\
\text { incentives) }\end{array}$ \\
\hline \multicolumn{3}{|l|}{ Staff appraisal } \\
\hline $\begin{array}{l}\text { performance } \\
\text { appraisal }\end{array}$ & not obligatory and seldom & $\begin{array}{c}\text { obligatory for every official, } \\
\text { yearly target agreement }\end{array}$ \\
\hline $\begin{array}{l}\text { assessment of } \\
\text { future potential }\end{array}$ & $\begin{array}{l}\text { not obligatory and parallel to } \\
\text { performance appraisal }\end{array}$ & $\begin{array}{l}\text { obligatory for every official, } \\
\text { independent of } \\
\text { performance appraisal }\end{array}$ \\
\hline $\begin{array}{l}\text { senior staff } \\
\text { appraisal }\end{array}$ & none & $\begin{array}{l}\text { for every senior official at } \\
\text { regular intervals }\end{array}$ \\
\hline $\begin{array}{l}\text { use of staff } \\
\text { appraisal results }\end{array}$ & $\begin{array}{l}\text { hardly connected to } \\
\text { promotion (seniority } \\
\text { principle) and incentives }\end{array}$ & $\begin{array}{l}\text { directly connected to } \\
\text { promotion and awarding of } \\
\text { incentives }\end{array}$ \\
\hline $\begin{array}{l}\text { Training } \\
\text { budget and hours of } \\
\text { training }\end{array}$ & constant and low & increasing and appropriate \\
\hline $\begin{array}{l}\text { purpose } \\
\text { management } \\
\text { training for senior } \\
\text { staff }\end{array}$ & $\begin{array}{l}\text { no explicit strategy } \\
\text { voluntary and limited offer of } \\
\text { courses }\end{array}$ & $\begin{array}{l}\text { lifelong learning } \\
\text { compulsory and variety of } \\
\text { courses }\end{array}$ \\
\hline
\end{tabular}

ex-members of the Commissioners' cabinets receive tenure more easily than other candidates. Another phenomenon is the 'submarine approach', where officials already in possession of fixed-term contracts receive tenure without any 
selection procedure (Stevens and Stevens 2001). Until the late 1990s, the selection procedure for senior staff was barely formalized and their profile was primarily based upon their expertise (Bauer 2008). Since 2001, however, senior staff are recruited by posting of the vacancy internally, rarely also externally. The recent reforms want the head of a unit to be more of a manager than an expert (interview 12/05/2006). For this purpose, the new selection procedure contains an additional layer, the 'assessment centre method', where candidates have to prove generic competences to become senior managers. The introduction of activity-based management also makes senior staff more accountable in fulfilling certain policy outputs. However, indefinite contracts still limit personal responsibility and officials normally keep their positions until they retire.

The European Commission's career structure can be classified as a typical career-based system. Entrance usually takes place at the first level (grade) of the respective career. However, the structure has changed considerably. In 1995 it has composed of four horizontal categories with four to eight grades, respectively. The professional staff belonged to category $\mathrm{A}$, followed hierarchically by categories $\mathrm{B}, \mathrm{C}$ and $\mathrm{D}$. The translators and interpreters had their own career path named LA. At that time, it was difficult to be promoted more than two or three times so many officials reached the highest grade after 15 to 20 years of service (Stevens and Stevens 2001). The new system, by contrast, contains two function groups and 16 grades. The categories $\mathrm{B}$ and $\mathrm{C}$ are now classified as 'assistants' (AST 1-11) and the categories A and LA as 'administrators' (AD 5-16). This structure is more vertical and allows for more merit-based promotion than before (European Commission 2004; interview 12/05/2006). After the reform, officials with management responsibilities earn more than their counterparts in the grade without this responsibility, though basic salary is still not linked to the job, but to the grade a person holds. In addition to the basic salary, officials receive seniority steps that are paid automatically. During the period of investigation they were reduced from eight to five per grade in order to increase the weight of merit and reduce the weight of seniority (interview 12/05/2006). There are still overlaps between the grades, i.e. an assistant with higher seniority can earn more than an administrator. However, the salary increase now proceeds digressively. This means that, after the reform, an official more quickly reaches a position where he does not receive any extra pay simply by staying in his job. This way, the Commission wants to motivate officials to make an effort for promotion. Finally, there is a merit bonus.

The staff appraisal system has also changed considerably. Now performance appraisal contains a target agreement and is conducted every year and independently of the new assessment of future potential. The appraisal of senior staff was introduced as a pilot scheme and is not yet institutionalized. An important goal during the reform process was to enhance the efficient use of staff appraisals as a basis for merit-based promotion. In 1995, almost all officials were promoted automatically because of the seniority principle. The performance appraisals did not serve as a valid instrument, because nearly all officials received the 
mark 'good' (interview 12/05/2006). Therefore, a new catalogue of criteria and marks was introduced containing up to 32 merit and priority points. Officials can now accumulate their points and are promoted when they reach a certain threshold. However, for officials with average performance, automatic promotion still exists. See Table 2 for an overview.

In the 1990s, training was not an explicit priority of the Commission. The budget was decreasing and officials attended training on average less than three days a year (Stevens and Stevens 2001: 106). Since 2000, however, the budget has more than doubled so officials now receive training on more than nine days a year (European Commission 2005). Connected to this financial investment was the implementation of a new strategy for a culture of lifelong learning. The goal is to make a more fine-tuned analysis of what each department or official needs and how training can help to deliver that by coaching, internal consultancy, paying for external training, etc. (interview 12/05/2006). The approach to management training was also revised. Senior staff with responsibility for financial and personnel resources are under an obligation to

Table 2 Range of reform in the European Commission

\begin{tabular}{|c|c|c|c|}
\hline Indicators & 1995 & 2007 & Change \\
\hline \multicolumn{4}{|l|}{ Recruitment } \\
\hline $\begin{array}{l}\text { selection procedure in } \\
\text { general }\end{array}$ & 2 & 2 & no change \\
\hline $\begin{array}{l}\text { selection procedure } \\
\text { for senior staff }\end{array}$ & 0 & 1 & towards NPM, but still closer to BM \\
\hline profile of senior staff & 0 & 2 & towards NPM, but still closer to BM \\
\hline \multicolumn{4}{|l|}{ Career structure } \\
\hline entrance & 1 & 2 & towards NPM, but still closer to BM \\
\hline structure & 0 & 3 & towards NPM \\
\hline basic salary & 0 & 1 & towards NPM, but still closer to BM \\
\hline extra pay & 0 & 2 & towards NPM, but still closer to BM \\
\hline merit bonus & 0 & 0 & no change \\
\hline \multicolumn{4}{|l|}{ Staff appraisal } \\
\hline performance appraisal & 1 & 4 & towards NPM \\
\hline $\begin{array}{l}\text { assessment of future } \\
\text { potential }\end{array}$ & 0 & 4 & towards NPM \\
\hline senior staff appraisal & 0 & 1 & towards NPM, but still closer to BM \\
\hline $\begin{array}{l}\text { use of staff appraisal } \\
\text { results }\end{array}$ & 0 & 2 & towards NPM, but still closer to BM \\
\hline \multicolumn{4}{|l|}{ Training } \\
\hline $\begin{array}{l}\text { budget and hours of } \\
\text { training }\end{array}$ & 0 & 4 & towards NPM \\
\hline purpose & 0 & 4 & towards NPM \\
\hline $\begin{array}{l}\text { management training } \\
\text { for senior staff }\end{array}$ & 0 & 4 & towards NPM \\
\hline
\end{tabular}


attend management courses. On top of this, it is no longer possible to be promoted to a management position without having taken those courses.

\section{The reform of human resource management in the OECD}

The staff regulations and rules apply to the 2,000 permanent officials in Paris, of whom about 60 per cent have fixed-term and 40 per cent indefinite contracts (OECD 2004). In addition, there are specific regulations for around 300 short-term employees like consultants, trainees and auxiliaries, who, however, are excluded from our analysis.

Starting with the dominant principles in recruitment, we find minor changes towards NPM during the observation period, with the merit principle playing a major role (interview 15/03/2006). Though the OECD tries to achieve a good mix of representation of member states ('national balance'), there is no institutionalized committee which controls adherence to this goal. In contrast to the strong merit-based recruitment of regular staff, peculiarities with regard to the so-called project staff have to be emphasized. The latter refers to OECD officials financed by voluntary contributions from member states for certain projects and positions. It is at the discretion of the OECD directorate that receives the contributions whether the position is advertised, and whether the applicants go through structured selection processes. When it comes to the recruitment of senior staff, it is at the discretion of the Secretary General whether these positions are advertised. However, in early 2000, the OECD adopted a policy that all senior staff are to be on fixed-term contracts. These contracts are only renewed if performance is satisfactory. Even internal appointees promoted through an internal process have to relinquish their indefinite contracts if they have them. The profile of senior staff is still their expertise although, since the introduction of activity-based management, they are subject to strong performance discipline (interview 15/03/2006). This means that they are accountable and responsible for outputs laid down in the programme of work and budget. Nevertheless, there is no regulation that makes management skills a sine qua non for senior positions.

The career structure has remained almost unchanged since the establishment of the OECD. Every position is open to competition so that lateral entrance into the structure is the norm. This structure is composed of the categories A, L, B and $C$, each having again several seniority steps (OECD 2007). Category $A$ is formed of professional staff ( 45 per cent), administrative and support staff are in category B, manual or technical staff are in category $\mathrm{C}$, and linguistic staff belong to category L. This system is hierarchical and tends to make it difficult for officials to progress (interview 15/03/2006). Since the introduction of result-oriented budgeting, some member states have perceived increasing problems in deploying staff flexibly, i.e. in shifting them from one priority task to another (interview 17/03/2006). Some member states even believe that the actual system bars the OECD from attracting and recruiting the best specialists. Furthermore, basic salary is dependent on grade and not (necessarily) 
on the task or responsibility which a person has. In addition, OECD officials automatically receive extra pay by seniority steps. Seldom is this disbursement delayed for a determined period of time because of bad performance (interview 16/03/2006). Senior staff members (grades A7 and A6) account for six to eight possible steps, the other grades for ten to eleven. The higher a person rises, the more extra pay increases. In connection with basic salary, this leads to an overlapping of grades so that a superior can earn less than his subordinate. Here is an example (interview 17/05/2006): it is only after ten years that a newly recruited superior in grade A5 would reach the salary level of his subordinate in grade A4, who has already received all possible seniority steps. The seniority principle is therefore quite important; performance-related pay does not exist. However, it is possible for the Secretary General to award an official with one or more extra seniority steps in return for particular efforts (merit bonus).

Concerning staff appraisal, the whole system was reformed in 1999. Performance appraisal is now binding on all officials and is conducted with target agreements on a yearly basis. The assessment of future potential is also compulsory. At the moment, in some directorates, there are optional '360-degree feedbacks' for the appraisal of senior staff. It is planned to use the results as a basis for promotion and not length of service (interview 15/03/2006). However, the five-point scale and the written assessment as a set of criteria for staff appraisals are not sufficiently linked to promotion or prolongation of contracts (interview 16/03/2006; interview 17/05/2006). From 1995 to 2004 the budget for training decreased considerably and reached a very low level (interview 14/03/2006). ${ }^{1}$ At the moment, the OECD is rethinking its approach to training, because until now no clear strategy was pursued. See Table 3 for an overview.

\section{The scale of human resource management reforms in comparison}

In Table 4, we analyse the scale of reform by comparing the changes in the distance to the ideal type NPM model for both organizations for 1995 and 2007. In 1995, we find that the human resource management of the OECD was clearly more in line with NPM principles than that of the Commission. Recruitment in general and lateral entrance into the career even corresponded to the NPM ideal type. By contrast, almost all indicators reveal an adherence to the $\mathrm{BM}$ model in the case of the Commission.

Ten years later, in recruiting staff, the OECD still corresponds more to NPM than the Commission. On the one hand, this is because of the fact that, contrary to the Commission, OECD senior staff members have exclusively performancelinked and temporary contracts. On the other hand, the 'merit principle' is, despite recent problems with the recruitment of project staff, more important than in the Commission. By contrast, the Commission reformed its career structure, which is now based on two function groups. In comparison to the OECD, it provides more opportunities for advancement and less visible overlap of grades. In addition, managers in the Commission receive a basic salary that reflects their duties more accurately than before. Only entrance to 
Table 3 Range of reform in the OECD

\begin{tabular}{|c|c|c|c|c|}
\hline Indicators & 1995 & 2007 & \multicolumn{2}{|l|}{ Change } \\
\hline \multicolumn{5}{|l|}{ Recruitment } \\
\hline $\begin{array}{l}\text { selection procedure in } \\
\text { general }\end{array}$ & 3 & 3 & no change & \\
\hline $\begin{array}{l}\text { selection procedure } \\
\text { for senior staff }\end{array}$ & 1 & 3 & towards NPM & \\
\hline profile of senior staff & 1 & 3 & towards NPM & \\
\hline \multicolumn{5}{|l|}{ Career structure } \\
\hline entrance & 4 & 4 & no change, yet NPM & \\
\hline structure & 0 & 0 & no change & \\
\hline basic salary & 0 & 0 & no change & \\
\hline extra pay & 1 & 1 & no change & \\
\hline merit bonus & 1 & 1 & no change & ath $5 x+2 x$ \\
\hline Staff appraisal & & & 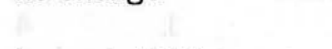 & \\
\hline performance appraisal & 1 & 4 & towards NPM & \\
\hline $\begin{array}{l}\text { assessment of future } \\
\text { potential }\end{array}$ & 0 & 4 & towards NPM & \\
\hline senior staff appraisal & 0 & 1 & towards NPM, but still & closer to BM \\
\hline $\begin{array}{l}\text { use of staff appraisal } \\
\text { results }\end{array}$ & 1 & 1 & no change & \\
\hline \multicolumn{5}{|l|}{ Training } \\
\hline $\begin{array}{l}\text { budget and hours of } \\
\text { training }\end{array}$ & 1 & 0 & towards BM & \\
\hline purpose & 1 & 1 & no change & \\
\hline $\begin{array}{l}\text { management training } \\
\text { for senior staff }\end{array}$ & 1 & 1 & no change & \\
\hline
\end{tabular}

the OECD's career structure is closer to the NPM ideal type, as is the case for the Commission.

Both organizations adapted their performance appraisals to NPM and conduct appraisals of senior staff on an optional basis. However, a fundamental difference is based on the fact that Commission officials with consistently good performance are automatically promoted once they pass a certain threshold of points. In the OECD, performance appraisals are to a lesser extent formally connected to promotion or prolongation of contracts. Finally, different reform efforts are demonstrated most clearly with regard to training. While the Commission reformed substantially, for the OECD it is the weakest element of human resource management. There is no explicit strategy comparable to lifelong learning in the Commission and the number of training hours per employee decreased considerably.

To conclude, the Commission's human resource management was reformed further (range), and even more comprehensively (scale), than in the OECD. In the following section, we try to answer the question as to how this variation can be explained. 
Table 4 Scale of reforms in the European Commission and the OECD (1995-2007)

\begin{tabular}{|c|c|c|c|c|c|c|}
\hline Indicators & $\begin{array}{c}\text { COM } \\
(1995)\end{array}$ & $\begin{array}{c}\text { OECD } \\
(1995)\end{array}$ & $\begin{array}{c}\text { closer to } \\
\text { NPM }\end{array}$ & $\begin{array}{c}\text { COM } \\
\text { (2007) }\end{array}$ & $\begin{array}{c}\text { OECD } \\
\text { (2007) }\end{array}$ & $\begin{array}{c}\text { closer to } \\
\text { NPM }\end{array}$ \\
\hline \multicolumn{7}{|l|}{ Recruitment } \\
\hline $\begin{array}{l}\text { selection } \\
\text { procedure in } \\
\text { general }\end{array}$ & 2 & 3 & OECD & 2 & 3 & OECD \\
\hline $\begin{array}{l}\text { selection } \\
\text { procedure }\end{array}$ & 0 & 1 & OECD & 1 & 3 & OECD \\
\hline $\begin{array}{l}\text { for senior } \\
\text { staff }\end{array}$ & & & & & & \\
\hline $\begin{array}{l}\text { profile of } \\
\text { senior staff }\end{array}$ & 0 & 1 & OECD & 2 & 3 & - \\
\hline \multicolumn{7}{|l|}{ Career structure } \\
\hline entrance & 1 & 4 & OECD & 1 & 4 & OECD \\
\hline structure & 0 & 0 & - & 3 & 0 & $\mathrm{COM}$ \\
\hline basic salary & 0 & 0 & - & 1 & 0 & $\mathrm{COM}$ \\
\hline extra pay & 0 & 1 & - & 2 & 1 & COM \\
\hline merit bonus & 0 & 1 & OECD & 0 & 1 & OECD \\
\hline \multicolumn{7}{|l|}{ Staff appraisal } \\
\hline $\begin{array}{c}\text { performance } \\
\text { appraisal }\end{array}$ & 1 & 1 & - & 4 & 4 & - \\
\hline $\begin{array}{l}\text { assessment of } \\
\text { future } \\
\text { potential }\end{array}$ & 0 & 0 & - & 4 & 4 & - \\
\hline $\begin{array}{l}\text { senior staff } \\
\text { appraisal }\end{array}$ & 0 & 0 & - & 1 & 1 & - \\
\hline $\begin{array}{l}\text { use of staff } \\
\text { appraisal } \\
\text { results }\end{array}$ & 0 & 1 & OECD & 2 & 1 & com \\
\hline \multicolumn{7}{|l|}{ Training } \\
\hline $\begin{array}{l}\text { budget and } \\
\text { hours of } \\
\text { training }\end{array}$ & 0 & 1 & OECD & 4 & 0 & COM \\
\hline purpose & 0 & 1 & OECD & 4 & 1 & COM \\
\hline $\begin{array}{l}\text { management } \\
\text { training for } \\
\text { senior staff }\end{array}$ & 0 & 1 & OECD & 4 & 1 & $\mathrm{COM}$ \\
\hline
\end{tabular}

\section{HOW TO EXPLAIN THE EMPIRICAL PUZZLE? THE LIMITS OF ISOMORPHISM THEORY}

When trying to account for the rather surprising empirical findings, we can generally differentiate between endogenous and exogenous factors. A first approach would certainly be to focus upon endogenous, i.e. internal, characteristics within 
both organizations. In particular, one thinks of different internal problem pressures (owing to the perception and politicization of performance deficits) in order to cope with the different scale of reforms. Performance crises especially, which attract considerable public attention, are emphasized as potential driving forces for administrative reforms (Bauer 2008; Pollitt and Bouckaert 2004). Indeed, both the European Commission and the OECD were confronted with internal corruption allegations in the late 1990s (Peterson 2004; Stevens and Stevens 2006). To be sure, the two crises were quite different in terms of media attention and politicization; the Santer Commission even resigned in the course of the developments, while the problems within the OECD hardly attracted much public attention. These differences, however, barely constitute a plausible explanation for the observed variation in organizational change at both Commission and OECD level, given that the crises concerned primarily antiquated and opaque accounting procedures. The topic of human resource management played only a minor role in this context. Moreover, though performance deficits owing to existing staff rules and regulations were raised internally in both organizations (European Commission 2000; OECD 1999: 32; OECD 2001: 97; OECD 2003: 94; OECD 2006: 102-3), our analysis has shown that the adoption and formal implementation of respective reforms differ sharply in our cases. ${ }^{2}$

Apart from problem pressure, there are other endogenous factors like the nature of the organization and its organizational size that may offer an explanation (cf. Knill and Bauer 2007). But there seems to be no discernible connection between the size and the competences of an international organization and its reform efforts in human resource management. This is at least the case if organizations dispose of a minimum number of employees and cover a certain scope of tasks - like the European Commission and the OECD do.

In view of this, the crucial question is why similar internal arrangements and problems led to far-reaching reforms in the Commission but not in the OECD. Are there differences in the environment of each organizations that can account for our empirical results? To answer this question, institutional isomorphism emerged as a promising framework, as it accounts for the phenomena of the international spread and diffusion of policy innovations and reform concepts, not least with regard to public sector reforms (DiMaggio and Powell 1991; Levi-Faur 2002; Meyer and Rowan 1977; Meyer et al. 1997). The central argument advanced by DiMaggio and Powell is that legitimacy rather than efficiency is the major driving force of organizational change. To increase their legitimacy and ensure their persistence, organizations embrace rules, norms and routines that are widely valued in their organizational environment.

Hence, organizational change is essentially driven by external developments rather than intra-organizational concerns about the organization's efficiency. DiMaggio and Powell identify three mechanisms which drive isomorphic organizational change, namely coercive, mimetic and normative isomorphism. In the following text, these mechanisms will be investigated in closer detail. 


\section{Coercive isomorphism}

An important driving force of isomorphic organizational change emerges from coercion. Organizations adjust their structures and procedures to be in line with organizations on which they are financially or legally dependent. According to these considerations, DiMaggio and Powell (1991: 74) hypothesize that 'the greater the dependence of an organization on another organization, the more similar it will become to that organization in structure, climate, and behavioral focus.'

Looking at our cases of human resource management reforms in the European Commission and the OECD, this kind of dependence might especially result from potential pressures exerted by the member states. In both organizations, the member states could, in principle, exert financial and political pressure to adjust existing management structures, as they play a crucial role in defining the budget of these organizations. In this context, dependence with regard to introducing NPM-based human resource management structures is assumed to vary with three factors.

First, the budgetary contributions might vary across member states, implying that the OECD and the European Commission are not equally dependent on each member state. In view of our research question, it is of particular importance whether member states that can be characterized as NPM core countries, or member states that are laggards in introducing NPM reforms at home, are more influential in terms of political decisions and budgetary contributions. To account for this variation, we divide the member states of the OECD and the Commission into two groups of NPM core countries and NPM laggards, and measure the number of votes each group has in the Council as well as its respective budget contribution. This classification is based on common distinctions in the respective literature (cf. Hood 1995; Kim 2002; OECD 1995; Pollitt and Bouckaert 2004). In this context, we assume that no significant changes in the classification of the member states occurred during the observation period 1995-2007. This assumption is supported by comparing respective assessments in the literature. The groups of NPM leader and laggard member states are summarized in Table 5.

Second, the budgetary pressures exerted by the member states might increase with the size of the personnel budget in relation to the overall budget. Third, the more an organization disposes of own resources which cannot be influenced by the member states, pressure on the personnel budget may be reduced.

Table 6 summarizes the characteristics which the OECD and the Commission display with regard to the three above-mentioned indicators (cf. European Commission 2006; OECD 2006, 2005a). On all indicators, it becomes apparent that we should expect more NPM-based changes of human resource management in the OECD than in the Commission. While in the European Union (EU), the share of Council votes of NPM laggards is more than twice as high as those of the NPM core countries, this difference is much less pronounced in the OECD. A similar picture emerges for the structure of the 
Table 5 NPM leader and laggard states in the EU and the OECD

\begin{tabular}{lcc}
\hline Group & \multicolumn{1}{c}{ EU } & \multicolumn{1}{c}{ OECD } \\
\hline NPM leaders & $\begin{array}{c}\text { Denmark, Finland, the United } \\
\text { Kingdom, Ireland, the } \\
\text { Netherlands, Sweden }\end{array}$ & $\begin{array}{c}\text { Australia, Canada, Denmark, } \\
\text { Finland, the United } \\
\text { Kingdom, Ireland, New } \\
\text { Zealand, the Netherlands, } \\
\end{array}$ \\
& & Norway, Sweden, \\
& & Switzerland, the USA \\
NPM laggards & Austria, Belgium, France, & Austria, Belgium, France, \\
& Germany, Greece, Italy, & Germany, Greece, Italy, \\
& Portugal, Spain & Japan, Mexico, Portugal, \\
& South Korea, Spain, Turkey \\
Other (lack of & Luxembourg & Czech Republic, Hungary, \\
data) & & Iceland, Luxembourg, \\
& & Poland, Slovakia \\
\hline
\end{tabular}

budget and respective budgetary contributions. More than 50 per cent of the EU budget is financed by NPM laggards, such as Germany, France, Italy and Spain. In sum, it is obvious that we should expect more pronounced NPM-oriented reforms in the OECD than in the Commission. Our empirical findings, by contrast, show exactly the opposite pattern. This leads us to the conclusion that coercive isomorphism does not seem to play a significant role in the reform process.

\section{Mimetic isomorphism}

Organizational adjustment to the environment is not only expected to take place as a result of coercive pressures, but may also occur in constellations of high

Table 6 Indicators of coercive reforms

\begin{tabular}{lrc}
\hline Indicator & $E U$ & OECD \\
\hline Number of Council votes & & \\
$\ldots$ of NPM leaders & $32.1 \%$ & $36.7 \%$ \\
$\ldots$ of NPM laggards & $65.6 \%$ & $43.3 \%$ \\
$\ldots$ of other member states & $2.3 \%$ & $20.0 \%$ \\
Relative budget contribution & & \\
own resources & $27.0 \%$ & $7.3 \%$ \\
$\ldots$ of NPM leaders & $19.6 \%$ & $33.1 \%$ \\
$\ldots$ of NPM laggards & $53.2 \%$ & $41.2 \%$ \\
$\ldots$ of other member states & $0.2 \%$ & $1.0 \%$ \\
Relative size of the personnel budget & $2.5 \%$ & $47.2 \%$ \\
\hline
\end{tabular}

Note: ${ }^{*}=$ plus voluntary contributions. 
uncertainty; for example, ambiguous goals, uncertain means-end relations or confrontation of new problems. In such constellations it is argued that organizations imitate the structures of other organizations which they perceive as particularly successful. Instead of a long-winded search for own solutions to existing problems, organizations strive to ensure their legitimacy by emulation (DiMaggio and Powell 1991: 75; Guler et al. 2002: 213).

With regard to potential uncertainty affecting human resource management reforms in the Commission and the OECD, we concentrate in the following text on the financial and personnel resources of these organizations. To what extent can they trust in the continuous development of their financial and personnel means? These factors are measured by three indicators, namely the length of the budgetary period as well as the development of the budget and staff numbers during the observation period (1995-2007). The more uncertain the situation of an organization with regard to these aspects (expressed by short budgetary periods and decreasing budget and staff size), the more we should expect the imitation of NPM-oriented management reforms. This expectation is based on the general observation that, during the last two decades, NPM has developed into a dominant reform approach around the globe, notwithstanding persistent differences in the speed and scope of adoption across countries (Pollitt and Bouckaert 2004).

When looking more closely at the different indicators, we arrive again at the conclusion that mimetic isomorphism is more likely in the OECD than in the Commission. This becomes apparent first in the fact that financial planning within the EU is based on a relatively long period; the member states decide every seven years on the financial framework for the yearly budget. In the OECD, by contrast, the budget is based on yearly and (from 2007 onwards) biannual decisions of the Council. Compared to the Commission, there is hence more uncertainty with regard to financial planning in the OECD.

Second, long-term financial planning in the $\mathrm{EU}$ at the same time implies that, during the observation period, both the size of the yearly budget and personnel resources within the Commission remain very stable. In the OECD, by contrast, on both indicators significant decreases can be observed from the late 1990s onwards. Between 1996 and 1999, the member states decided to cut the OECD budget by 18 per cent, implying that the OECD had to cut 220 jobs (OECD 1997a: 93; OECD 1999: 32). This development was triggered by reductions in the financial contributions of the United States, which also induced other members to reduce their payments. As a consequence, staff numbers fell by 10 per cent between 1995 and 2005, although five new members joined the organization during this period (the Czech Republic, Hungary, Poland, Slovakia and South Korea). Moreover, the OECD's nominal budget in 2007 was below the 1995 figures (OECD 1996, 2000, 2006), implying - as one OECD official states - that 'you have to do the same amount of work with less money' (interview 17/03/2006).

Hence, we find that the variation in human resource management reforms between the Commission and the OECD cannot be explained by mimetic 
isomorphism. Given much higher uncertainty with regard to financial and human resource planning, NPM-oriented reforms were much more likely to take place in the OECD than in the Commission.

\section{Normative isomorphism}

A further mechanism driving isomorphic organizational change is based on similar dominant normative orientations and the beliefs of staff members. In this context, the impact of similar professional backgrounds and the role of professional organizations and epistemic communities (Haas 1992) in spreading common understanding and perceptions of policy problems and solutions are emphasized in the literature (Hasse and Krücken 2005: 26).

In terms of professional standards (education, academic background), similar orientations can be assumed for the OECD and the Commission. In both organizations, staff are recruited from the best-educated academics in Europe (Hooghe 2001; Spescha 2005). Against this background, we consider it more appropriate to focus on the home country of the staff members rather than their educational background. This focus is also used by other studies, such as that by Hooghe (2001). In her study of decision-making within the European Commission, she found that the Commission bureaucrats, in many instances, define their respective positions by taking account of the 'majority opinion' in their home countries. For our concrete case of human resource management, we should therefore expect that the support of staff members for NPM-oriented reforms depends on the extent to which such developments were adopted or are supported in their home countries. The higher the number of staff from NPM core countries, the more the organization will adopt NPM-based reforms.

This argument, however, needs further explication. First, it can be assumed that the extent to which staff members perceive themselves as associated with the dominant beliefs and positions of 'their' national context decreases over time. The longer the tenure of officials, the more socialization with the orientations and goals of the international organization will become dominant over their domestic socialization (cf. Hooghe 2001: 211). Second, the extent to which officials might act as agents of diffusion within the international organization is dependent upon their degree of embeddedness in international discourses and networks in which issues of human resource management are debated.

To analyse the Commission and the OECD along the above-mentioned indicators, we concentrate on staff with academic backgrounds and top administrative officials in both organizations (European Commission 2007a; OECD 2004). For overall staff figures, we focus on all officials within the career track $A$ at the OECD level (906 individuals in 2004) and the new career track AD at the Commission level $\left(10,184\right.$ individuals in 2007). ${ }^{3}$ With regard to top officials, we consider the nationality of grades A6 and A7 (53 persons) in the OECD and of A1 and A2 (275 individuals) in the Commission. The staff composition of the Commission and the OECD according to these dimensions is shown in Table 7. 
Table 7 Nationality of staff and top officials in the European Commission and the OECD

\begin{tabular}{lrc}
\hline Indicator & COM & $O E C D$ \\
\hline Whole staff with academic background & & \\
$\ldots$ from NPM leaders & $26.8 \%$ & $48.5 \%$ \\
$\ldots$ from NPM laggards & $73.8 \%$ & $49.0 \%$ \\
$\ldots$ from other member states & $0.4 \%$ & $2.5 \%$ \\
Top officials & & \\
$\ldots$ from NPM leaders & $31.3 \%$ & $56.6 \%$ \\
$\ldots$ from NPM laggards & $68.6 \%$ & $43.4 \%$ \\
$\ldots$ from other member states & $0.1 \%$ & $0 \%$ \\
\hline
\end{tabular}

Looking at top officials, we find that within the Commission around twothirds of personnel are nationals of NPM laggard countries, basically from France, Germany, Belgium, Italy and Spain. Less than a third of the staff have the nationality of an NPM core country. This picture is even more pronounced when looking at all the staff with academic backgrounds. In the OECD, by contrast, top officials from NPM core countries make up 56.6 per cent, while for the entire staff the share of NPM leaders and laggards is almost equal. Based on these figures, mechanisms of normative isomorphism with regard to NPM-based reforms should be more pronounced for the OECD than for the Commission.

This expectation, which is contrary to our empirical results, is further supported when considering the length of time during which staff are typically employed in both organizations. In the OECD, only 30 per cent of the top officials and 45 per cent of the entire staff have time unrestricted working contracts, while in the Commission almost all staff members have tenure. Compared to the Commission, we can hence assume staff socialization in the OECD to be based much more on the national context rather than shaped by the organization itself. This should facilitate the transfer of dominant domestic ideas with regard to human resource management into the organization.

The same statement applies with regard to the involvement of staff members in international communities and networks in which NPM and human resource management reforms are discussed. While the Commission is predominantly concerned with issues of drafting and policy formulation, the OECD perceives itself primarily as a think-tank which, via its Public Management Committee (PUMA), ${ }^{4}$ explicitly acted as the international promoter of NPM-based human resource management (OECD 1995; Sahlin-Andersson 2002). Against this backdrop, it is almost ironic that the OECD recently announced a new report on 'modernizing public employment' in order to push respective reforms in its member states (OECD 2005b), while at the same time keeping rather 'old-fashioned structures' at home.

In summary, we find that the different mechanisms of coercive, mimetic and normative isomorphism do not provide a sufficient explanation of the variation 
in human resource management structures found in the OECD and the European Commission. While isomorphic changes towards NPM-based structures should be more pronounced in the OECD than in the Commission, empirical findings reveal exactly the opposite pattern. Therefore, the central puzzle emerging from our analysis is: Why did the OECD not embrace, to a similar and even stronger extent, NPM-based human resource management reforms as the Commission did? We argue in the following text that this puzzle can be addressed by close investigation of the limits of the mechanisms of institutional isomorphism.

\section{SCOPE CONDITIONS OF ISOMORPHIC CHANGE}

It is an important achievement of isomorphism theory that it differentiates between the mechanisms that drive organizational change. Moreover, the theory identifies the factors that affect the relative importance of each mechanism in a specific constellation; for example coercive isomorphism is more pronounced, the more an organization is dependent on other organizations. What is theoretically underdeveloped, however, is the fact that - in many instances - organizations will have multiple choices when striving to increase their legitimacy in their organizational environment. On the one hand, there might be more than one dominant model that could serve as a blueprint for change. On the other hand, and this is of special importance in our case, isomorphic change might refer to different dimensions, levels or aspects of existing organizational structures, routines and practices. In other words, it is unclear under what conditions an organization decides to reform, for instance, its formal structure, its decision-making procedures or its human resource management. Which parts of the menu of potentially legitimacy-enhancing reform models circulating in the international environment do organizations actually select and why?

We argue in the following text that organizations base these decisions upon the relative legitimacy gains to be derived from the varying options for isomorphic change. The case of the OECD shows that these potential gains are strongly affected by the specific legitimacy problems with which an organization is confronted. Given the OECD's rather fundamental crisis with regard to its self-identity and future development, isomorphic adjustments to its human resource management were not a sufficient remedy to overcome this crisis.

First, since the 1990s the OECD has experienced a fundamental crisis with regard to the definition of its future objectives and mission. ${ }^{5}$ As its then General Secretary Johnston emphasized in 1997: 'it has become clear that the OECD suffers from a lack of distinct identity ... Dealing with the full range of public policy issues it has become increasingly difficult to capture in a few descriptive words what the Organization actually does' (OECD 1997b: 3). Notwithstanding this early diagnosis, the OECD still lacks a clear focus and decision as to what to do with which member states (interview 16/03/2006; interview 17/03/2006). The new Secretary General Angel Gurría assumed office in 
June 2006 and asked - again - the member states to better define the OECD's role. He argued for a new and clear mandate; a mandate for relevance.

Conflicts about future goals are very difficult to resolve in view of internal decision-making structures based on unanimity. This is particularly true here, as the adoption of new goals in light of the tight budgetary situation would require a reduction in other activities. Such redistribution conflicts, however, are difficult to address within the existing structures (Chavranski 1997: 71; interview 17/03/2006). For the maintenance of the status quo, it is sufficient that there is only one member state objecting to the dissolution of a certain working group or committee. Overcoming this crisis requires respective adjustments in the decision-making procedures, an issue discussed for years, albeit without any solution on the horizon as yet.

A second related problem is the unresolved conflicts with regard to potential enlargements of the OECD. There is an ongoing debate about whether the organization should integrate bigger 'players', such as Brazil, China, Russia or India, or focus on the accession of Central and Eastern European countries. The longer this conflict over a more global or a more European focus lasts, the higher the risk that the OECD loses its profile or 'policy monopoly' to other international organizations, such as the EU, the International Monetary Fund, the World Bank or the World Trade Organization in the field of foreign trade and economic policy (interview 17/03/2006). This problem is further aggravated by the fact that, among the general public, there is decreasing perception and knowledge of the activities and achievements of the OECD. For instance, in most member states, the general public is not aware of the fact that the highly politicized 'Programme for International Student Assessment' (PISA) ranking was launched by the OECD.

In sum, we can observe a continuing identity crisis for the OECD that constitutes an important scope condition of isomorphic change. As the OECD's organizational environment is almost exclusively constituted by national governments and their civil servants attending respective meetings and working groups, the identity crisis also has an external dimension that can be termed a legitimacy crisis. Against this background, isomorphic adjustments to the OECD's human resource management were not a sufficient remedy to overcome this crisis. On the contrary, the member states did not agree upon substantive management reform but upon the reduction of costs by downsizing staff and reducing the budget for training. As far as the European Commission is concerned, such fundamental conflicts over objectives and challenges could not be identified. Owing to its seven-year financial framework and its political sovereignty, such problems are less likely to occur than in the OECD.

\section{CONCLUSION}

In this paper, we compared human resource management structures in the European Commission and the OECD, and their development towards NPM-based reform models between 1995 and 2007. Our results show that, 
overall, an orientation towards NPM models is more pronounced in the European Commission than in the OECD. This finding is striking from both an empirical and a theoretical perspective. First, it appears paradoxical that the OECD - considered to be one of the most important international promoters of NPM - has a rather old-fashioned human resource management that needs to be further improved and reformed in the future. Second, our empirical results conflict with theoretical expectations derived from institutional isomorphism: coercive, mimetic and normative pressures for NPM-based adjustments were stronger in the OECD than in the European Commission so that we should actually have observed opposite reform patterns. Against this background, our comparative analysis suggests that organizations are highly selective in terms of how to react to pressures for isomorphic change. Thus, we have argued that isomorphism theory needs to be complemented by arguments with regard to the conditions under which organizations adopt policy innovations which diffuse internationally. They seem to be contingent upon the specific problems with which an organization is confronted and the potential legitimacy gains for overcoming these problems.

Biographical note: Christoph Knill is Professor in the Department of Politics and Management at the University of Konstanz, Germany, and holds the Chair of Comparative Public Policy and Administration. Tim Balint is Ph.D. candidate at the same Chair.

Address for correspondence: Christoph Knill, Chair of Comparative Public Policy and Administration, University of Konstanz, Box D 91, D-78457 Konstanz, Germany. email: christoph.knill@uni-konstanz.de

\section{ACKNOWLEDGEMENTS}

We would like to thank Michael W. Bauer for organizing the inspiring conference on 'Management Reforms in International Organizations' at the University of Konstanz, 30 June-1 July 2006, where we presented an early version of this article. We are also grateful to three anonymous referees for their excellent comments.

\section{NOTES}

1 Thanks to helpful co-operation with the OECD, the authors received detailed information about the variable 'training' in order to validate the data (cf. Table 3). However, the specific content of these data cannot be made publicly available.

2 The OECD embarked on a major reform programme very recently. As this recent reform programme had not been completed and formally implemented at the time of this study, it is not covered in this article.

3 For the OECD, we relied on the most recent data available (OECD 2004). For the Commission, we took the 2007 data (European Commission 2007a) and excluded staff from the countries who joined the EU in 2004, assuming that the latter are of 
limited importance in accounting for reform developments between 1995 and 2007. In both organizations the national composition of the staff has remained stable over the last decade.

4 PUMA was renamed Public Governance and Territorial Development (GOV).

5 See also various reports in Financial Times, 2 March 2003, 30 November 2005, 29 May 2006; International Herald Tribune, 29 November 2005, 10 February 2006, 10 May 2006; Süddeutsche Zeitung, 15 March 2003.

\section{REFERENCES}

Barnett, M.N. and Finnemore, M. (1999) 'The politics, power, and pathologies of international organizations', International Organization 53(4): 699-732.

Barnett, M.N. and Finnemore, M. (2004) Rules for the World. International Organizations in Global Politics, Ithaca, NY: Cornell University Press.

Bauer, M.W. (2008) 'Diffuse anxieties, deprived entrepreneurs: Commission reform and middle management', Journal of European Public Policy 15(5): 691-707.

Bauer, M.W. and Knill, C. (eds) (2007) Management Reforms in International Organizations, Baden-Baden: Nomos.

Chavranski, H. (1997) L'OCDE: Au cour des grands débats économiques, Paris: La Documentation Française.

Davies, M.D.V. (2002) The Administration of International Organizations: Top Down and Bottom $U p$, Burlington, VT: Ashgate.

DiMaggio, P.J. and Powell, W.W. (1991) 'The iron cage revisited: institutional isomorphism and collective rationality in organizational fields', in W.W. Powell and P.J. DiMaggio (eds), The New Institutionalism in Organizational Analysis, Chicago: University of Chicago Press, pp. 63-82.

European Commission (2000) 'Reforming the Commission - A White Paper - Part I', document COM/2000/0200 final, Brussels.

European Commission (2004) 'Reforming the Commission. Human Resources'. Available: http://ec.europa.eu/reform/2002/index_en.htm [2007, July/01].

European Commission (2005) 'Communication from the Commission to the European Parliament and the Council: progress report on the Commission reform beyond the reform mandate', document COM(2005) 668, Brussels.

European Commission (2006) 'The European Union budget at a glance'. Available: http://ec.europa.eu/budget/budget_glance/index_en.htm [2007, July/01].

European Commission (2007a) 'Distribution of officials and temporary agents by nationality, category and grade (all budgets)'. Available: http://ec.europa.eu/ civil_service/docs/bs_sexe_nat_grade_en.pdf [2007, July/01].

European Commission (2007b) 'Staff regulations of officials of the European Commission'. Available: http://ec.europa.eu/dgs/personnel_administration/publications_en.htm [2007, July/01].

Geri, L.R. (2001) 'New public management and the reform of international organizations', International Review of Administrative Science 67(3): 445-60.

Guler, I., Guillén, M.F. and Macpherson, J.M. (2002) 'Global competition, institutions, and the diffusion of organizational practices: the international spread of ISO 9000 quality certificates', Administrative Science Quarterly 47(2): 207-32.

Haas, P.M. (1992) 'Introduction: Epistemic communities and international policy coordination', International Organization 46(1): 1-35.

Hasse, R. and Krücken, G. (2005) Neo-Institutionalismus, Bielefeld: Transcript.

Hood, C. (1991) 'A public management for all seasons?', Public Administration 69(1): 3-19.

Hood, C. (1995) 'The "new public management" in the 1980s: variations on a theme', Accounting, Organizations and Society 20(2/3): 93-109. 
Hooghe, L. (2001) The European Commission and the Integration of Europe. Images of Governance, Cambridge: Cambridge University Press.

Kim, P.S. (2002) 'Civil service reform in Japan and Korea: toward competitiveness and competency', International Review of Administrative Science 68(3): 389-403.

Knill, C. and Bauer, M.W. (2007) 'Theorizing management reforms in international organizations', in M.W. Bauer and C. Knill (eds), Management Reforms in International Organizations, Baden-Baden: Nomos, pp. 191-99.

Lægreid, P. (2002) 'Transforming top civil servant systems', in T. Christensen and P. Lægreid (eds), New Public Management. The Transformation of Ideas and Practice, Aldershot: Ashgate, pp. 145-72.

Levi-Faur, D. (2002) 'The politics of liberalization. Privatization and regulation for competition in Europe's and Latin America's telecoms and electricity industries', European Journal of Political Research 42(5): 705-40.

Liebel, H.J. and Oechsler, W.A. (1992) Personalbeurteilung. Neue Wege zur Bewertung von Leistung, Verhalten und Potential, Wiesbaden: Gabler.

Liese, A. and Weinlich, S. (2006) 'Die Rolle von Verwaltungsstäben internationaler Organisationen. Lücken, Tücken und Konturen eines (neuen) Forschungsfelds', in J. Bogumil, W. Jann and F. Nullmeier (eds), Politik und Verwaltung. Politische Vierteljahresschrift Sonderheft 37/2006, Wiesbaden: VS-Verlag für Sozialwissenschaften, pp. $491-524$.

Meyer, J.W. and Rowan, B. (1977) 'Institutionalized organizations. Formal structure as myth and ceremony', American Journal of Sociology 83(2): 340-63.

Meyer, J.W., Frank, D.J., Hironaka, A., Schofer, E. and Brandon-Tuma, N. (1997) 'The structuring of a world environmental regime, 1870-1990', International Organization 51(4): 623-51.

Naschold, F. and Bogumil, J. (2000) Modernisierung des Staates. New public management in deutscher und internationaler Perspektive, Opladen: Leske + Budrich.

OECD (1995) Governance in Transition. Public Management Reforms in OECD Countries, Paris: OECD.

OECD (1996) OECD Annual Report 1996, Paris: OECD.

OECD (1997a) OECD Annual Report 1997, Paris: OECD.

OECD (1997b) 'The OECD - challenges and strategic objectives: 1997 (Note by the Secretary General)', document C(97)180, Paris.

OECD (1999) OECD Annual Report 1999, Paris: OECD.

OECD (2000) OECD Annual Report 2000, Paris: OECD.

OECD (2001) OECD Annual Report 2001, Paris: OECD.

OECD (2003) OECD Annual Report 2003, Paris: OECD.

OECD (2004) 'Staff profile statistics', document C(2004)48, Paris.

OECD (2005a) 'Financial statement of the Organization for Economic Co-operation and Development as of 31 December 2005'. Available: http://appli1.oecd.org/ olis/2006doc.nsf/linkto/exd-bc(2006)1 [2007, July/01].

OECD (2005b) Modernising Government. The Way Forward, Paris: OECD.

OECD (2006) OECD Annual Report 2006, Paris: OECD.

OECD (2007) 'Human resource management at the OECD'. Available: http:// www.oecd.org/document/8/ 0,2340,en_2649_34481_20008648_1_1_1_1,00.html [2007, July/01].

Peterson, J. (2004) 'The Prodi Commission: fresh start or free fall?', in D.G. Dimitrakopoulos (ed.), The Changing European Commission, Manchester: Manchester University Press, pp. 15-32.

Pollitt, C. and Bouckaert, G. (2004) Public Management Reform. A Comparative Analysis, Oxford and New York: Oxford University Press. 
Sahlin-Andersson, K. (2002) 'National, international and transnational constructions of new public management', in T. Christensen and P. Lægreid (eds), New Public Management. The Transformation of Ideas and Practices, Aldershot: Ashgate, pp. 43-72.

Spescha, G. (2005) 'OECD und ihr Einfluss auf die nationale Politik - ein Streitgespräch', Die Volkswirtschaft 78(4): 29-33.

Stevens, A. and Stevens, H. (2001) Brussels Bureaucrats? The Administration of the European Union, Basingstoke: Palgrave Macmillan.

Stevens, H. and Stevens, A. (2006) 'The internal reform of the Commission', in D. Spence and G. Edwards (eds), The European Commission, London: John Harper, pp. 454-80.

Vaanholt, S. (1997) Human Resource Management in der öffentlichen Verwaltung, Wiesbaden: Deutscher Universitäts-Verlag.

\section{Summary of interviews}

\begin{tabular}{|c|c|c|}
\hline Interviews & Place & Interviewees \\
\hline $14 / 03 / 2006$ & Paris & $\begin{array}{l}\text { ambassador of OECD member } \\
\text { state }\end{array}$ \\
\hline $15 / 03 / 2006$ & Paris & $\begin{array}{l}\text { two employees of the OECD human } \\
\text { resource department }\end{array}$ \\
\hline $16 / 03 / 2006$ & Paris & $\begin{array}{l}\text { ambassador of OECD member } \\
\text { state }\end{array}$ \\
\hline $17 / 03 / 2006$ & Paris & $\begin{array}{l}\text { two representatives of the OECD } \\
\text { Staff Association, ambassador of } \\
\text { OECD member state, national } \\
\text { expert in OECD personnel policy }\end{array}$ \\
\hline $12 / 05 / 2006$ & Brussels & $\begin{array}{l}\text { seconded national expert for } \\
\text { reform of EU staff regulations, } \\
\text { two employees of DG Personnel } \\
\text { and Administration }\end{array}$ \\
\hline $17 / 05 / 2006$ & telephone interview & $\begin{array}{l}\text { ambassador of OECD member } \\
\text { state, national expert in OECD } \\
\text { personnel policy }\end{array}$ \\
\hline
\end{tabular}

